\title{
Biodiversity of fruit flies (Diptera, Tephritidae) in orchards in different agro-ecological zones of the Morogoro region, Tanzania
}

Maulid W. MwataWALA ${ }^{a}$, Marc De MeYeR ${ }^{b *}$, Rhodes H. MAKUnDI ${ }^{c}$, Amon P. MAereRE $^{a}$

a Department of Crop Science and Production, Sokoine University of Agriculture, Morogoro, Tanzania

b Entomology Section, Royal Museum for Central Africa, Tervuren, Belgium

marc.de.meyer@ africamuseum.be

${ }^{c}$ Pest Management Centre, Sokoine University of Agriculture, Morogoro, Tanzania
${ }^{*}$ Correspondence and reprints

Received 18 January 2006 Accepted 4 April 2006

Fruits, 2006, vol. 61, p. 321-332 (c) 2006 Cirad/EDP Sciences All rights reserved DOI: $10.1051 /$ fruits:2006031 www.edpsciences.org/fruits

RESUMEN ESPAÑOL, p. 332
Biodiversity of fruit flies (Diptera, Tephritidae) in orchards in different agroecological zones of the Morogoro region, Tanzania.

Abstract - Introduction. Fruit flies (Diptera, Tephritidae) are among the major constraints in commercial horticulture in many African developing countries. Knowledge of the tephritid spectrum in any given area is a prerequisite for the development of an IPM program to alleviate the pest problem. We studied the fruit fly diversity in four main agro-ecological zones which are significant fruit-producing areas in the Morogoro Region, Tanzania. Materials and methods. Fruit fly diversity was investigated for one year (October 2004 - October 2005). Parapheromones, synthetic food attractant and protein-bait traps were used to trap the flies at the different locations in Morogoro region. Tanzania. One mixed orchard was selected at each of four locations representing the different agro-ecological zones of the region. Results. The recently introduced alien species, Bactrocera invadens, and three indigenous pest species, Ceratitis rosa, Dacus bivittatus and D. punctatifrons, were found at all the four sites, while Bactrocera cucurbitae, Ceratitis cosyra, Dacus chiwira and D. humeralis were found in three out of the four sites. The Sokoine University of Agriculture (SUA) Horticulture Unit and Mikese sites had the highest species diversity while the Mkindo and Nyandira sites had the lowest diversity. The between-habitats diversity (Beta diversity) was similar among the SUA, Mkindo and Mikese sites. Only the Nyandira site had a higher dissimilarity in comparison with the other three sites. Discussion. The most abundant species at low- and mid-elevation sites was Bactrocera invadens while, at high elevation, Ceratitis ros $a$ was the dominant species. Protein-baited traps attracted the highest diversity of fruit flies in comparison with the more specific parapheromones. The synthetic food attractant (three-component lure) was less efficient compared with the protein bait. The large dissimilarity at the Nyandira site is probably due to the different types of host fruits found and grown in high altitude areas (mainly temperate fruits). Fruit fly species associated with these types of fruits, e.g., Ceratitis rubivora and Trirbithrum coffeae, were found only at this site.

Tanzania / fruit trees / Tephritidae / fruit flies / biodiversity / Ceratitis / Bactrocera / Dacus / surveys / traps / identification

Biodiversité des mouches des fruits (Diptera, Tephritidae) en vergers, dans différentes zones agro-écologiques de la région de Morogoro, Tanzanie.

Résumé - Introduction. Les mouches des fruits (Diptera, Tephritidae) font partie des principales contraintes de l'horticulture commerciale dans de nombreux pays africains en voie de développement. La connaissance du spectre des tephritides dans un secteur donné est un préalable au développement d'un programme d'IPM permettant d'atténuer le problème parasitaire. Nous avons étudié la diversité des mouches des fruits dans quatre principales zones agro-écologiques qui sont des zones de production fruitière significative dans la région de Morogoro, Tanzanie. Matériel et méthodes. La diversité des mouches des fruits a été étudiée pendant une année (octobre 2004 à octobre 2005). Des pièges à paraphéromones, attractifs alimentaires synthétiques et appâts protéinés ont été utilisés pour attraper les mouches dans différents endroits de la région de Morogoro. Un verger composite a été choisi pour chacun des quatre lieux représentatifs des différentes zones agro-écologiques de la région. Résultats. L'espèce étrangère Bactrocera invadens, récemment introduite, et trois espèces nuisibles indigènes, Ceratitis rosa, Dacus bivittatus et $D$. punctatifrons, ont été trouvées aux quatre emplacements prospectés, alors que Bactrocera cucurbitae, Ceratitis cosyra, Dacus chiwira et $D$. humeralis étaient identifiées dans trois emplacements sur les quatre visités. Les sites de l'université d'horticulture et d'agriculture de Sokoine (SUA) et de Mikese ont montré la diversité d'espèces la plus élevée tandis que les localités de Mkindo et de Nyandira révélaient une plus basse diversité. La diversité intra-habitats (bêta diversité) a été la même pour les sites de SUA, Mkindo et Mikese. Seule la localité de Nyandira a révélé une dissimilitude plus importante que celle des trois autres localisations. Discussion. L'espèce la plus abondante à basse et moyenne altitudes a été Bactrocera invadens, alors que, à altitude élevée, Ceratitis rosa a été l'espèce dominante. Les pièges avec appât protéiné ont attiré la plus forte diversité de mouches des fruits par rapport aux parapheromones plus spécifiques. L'attractif alimentaire synthétique (appât à trois composants) a été moins efficace comparé à l'appât protéiné. La grande dissimilitude observée à Nyandira est probablement due aux différents types de fruits hôtes trouvés et cultivés dans ce lieu d'altitude élevée, fruits d'espèces tempérées principalement. Des espèces de mouches des fruits associées à ces types de fruits, Ceratitis rubivora et Trirhithrum coffeae, par exemple, n'ont été trouvées qu'à cet emplacement.

Tanzanie / arbre fruitier / Tephritidae / mouche des fruits / biodiversité / Ceratitis / Bactrocera / Dacus / enquête / piège / identification 


\section{Introduction}

The Sub-Saharan African region is a growing center for tropical and subtropical fruit production and export. Its capacity is still relatively small, compared with South American or Asian markets, but it has been growing considerably in the past few years ${ }^{1}$. In addition, fruits supply an essential addition to local nutrition and generate income in these countries. For several tropical fruits, the production is mainly by smallholder producers largely intended for local consumption in the rapidly expanding local urban markets [1]. Tanzania's agro-based economy could be boosted by finding reliable markets for its non-traditional export crops such as fruits. However, reliable markets for fruits can be secured only when a country is able to produce high quality fruits, free from pests and diseases. Production of high quality fruits in Tanzania is hampered by economic and developmental constraints, but also by insect pests, especially fruit flies (Diptera: Tephritidae). Infestation by the latter is a major constraint to the local fruit production, e.g., losses of up to $40 \%$ are attributed to this in mangoes alone in East Africa [1]. The damage to fleshy fruits is probably mainly caused by a limited number of highly polyphagous species.

The status of fruit fly research in Tanzania has recently been reviewed [2]. It is shown that little has been done to study fruit flies in the country, especially to establish the quantitative and qualitative losses they cause in fruits. So far, there is no proper management program of fruit flies that has been formulated for smallholder farmers in Tanzania. Moreover, the situation has been worsened with the introduction into the country of the invasive fruit pest species Bactrocera invadens [3]. Bactrocera invadens occurs in large numbers and causes heavy losses in fruits, especially mangoes. In the country, Morogoro region is among the major fruit-producing areas. Both temperate and tropical fruits are produced in this agro-ecologically diverse region and most of these are attacked by different species of fruit flies. The losses are undoubtedly high, although they have not

${ }^{1}$ http://apps.fao.org/ been reliably quantified. In order to alleviate the situation, there is a need to formulate an ecologically-based Integrated Pest Management (IPM) program for fruit flies, because such programs are normally environmentally sustainable and economically affordable to smallholder farmers [4]. Fruits produced in such systems, which entail minimal or no use of pesticides, are of high quality, satisfying the minimum residue limits imposed on exporting countries.

Two of the important requirements for formulating an IPM program are to establish the diversity of the local fruit fly fauna and to determine parameters necessary for its formulation, including the population ecology of the involved species. Our paper reports on the diversity of fruit flies in Morogoro region, Tanzania, based on a oneyear trapping program. The alpha diversity (species richness or within-habitat diversity [5]) and beta diversity (differentiation diversity or between-habitats diversity [5]) at the different sites are analyzed. The study also compares the efficiency of lures at capturing the fruit flies at the different sites.

\section{Materials and methods}

\subsection{Study sites}

Surveys were conducted between September and October 2004 to select the experimental sites in the agro-ecological zones of Morogoro region. A total of four sites were selected (figure 1), including Sokoine University of Agriculture (SUA) Horticulture Unit (Morogoro urban District), a demonstration orchard in Nyandira-Tchenzema ward (Mvomero District), a commercial orchard in Mikese ward (Morogoro rural District) and a smallholder orchard in Mkindo ward (Mvomero District). The selection was based on agro-ecological characteristics and fruit production. Each site was characterized with an indication of geographical position, size and fruit varieties present (table I, II). Wild fruits (including cucurbits) growing in and around the different selected orchards were observed, but their inventory and identification was outside the scope of this research. 


\subsection{Trapping}

Trapping was conducted for one full year's cycle from mid-October 2004 to mid-October 2005. The focus was on fruit-infesting species, mainly Ceratitidine fruit flies, in particular the genera Ceratitis and Trirhithrum. The Dacine fauna, with special emphasis on B. invadens and some of the major cucurbitinfesting species, was also studied.

Modified McPhail traps baited with different types of lures (all purchased from Scentry, Montana, USA) were used. Trimedlure was used to attract members of the genus Ceratitis, sub-genera Ceratitis and Pterandus. Methyl eugenol was used to attract members of the genus Ceratitis subgenus Pardalaspis, as well as the invasive $B$. invadens. Cue Lure was used to attract members of Dacus and Bactrocera cucurbitae. An insecticide strip of dichlorovos (vapona) was placed in each trap to kill the adult flies. In addition, protein bait and single matrix synthetic food attractant (threecomponent lure, containing putrescine, ammonium acetate and trimethylamine) (also from Scentry Cie), which are less specific than the above mentioned lures, were also used to attract other fruit flies.

At SUA, two replicates for each bait type were put up in the mango (varieties 'Sindano Nyeusi' and 'Dodo') part, the same two replicates were put in the citrus (varieties 'Tahiti lime' and 'Sweet seedling') part, and one replicate in the guava (unknown variety) part of the orchard. In Mikese, four replicates (all under mango trees: varieties 'Tommy atkins', 'Maya', 'Red Indian' and 'Alphonso') while, at the other two sites, two replicates, also for each bait type, were set. In Mkindo, the baits were set under citrus trees of unknown variety, and, in Nyandira, under a peach tree of unknown variety and a plum tree of the variety 'Santa Rosa'. At all sites, the traps were hung on selected trees, placed 1.5-2 $\mathrm{m}$ above the ground. All the five traps were hung on the same tree and rotated clockwise after each emptying.

Traps were inspected and catches were collected once a week at the SUA Horticulture Unit, while lures and insecticide strips were changed at the end of every fourth week. The protein bait was replaced once a week. Flies were collected once a month in all the other stations. At these sites, lures and protein baits were placed every third week and left to stay for one week. After that, the lures were removed and discarded. Fruit flies were collected and placed into vials containing alcohol for preservation, labeled and transported to the laboratory for identification and counting.

Figure 1.

Location of four sites (indicated by stars) studied within Morogoro Region (Tanzania) to identify the biodiversity of fruit flies in orchards.

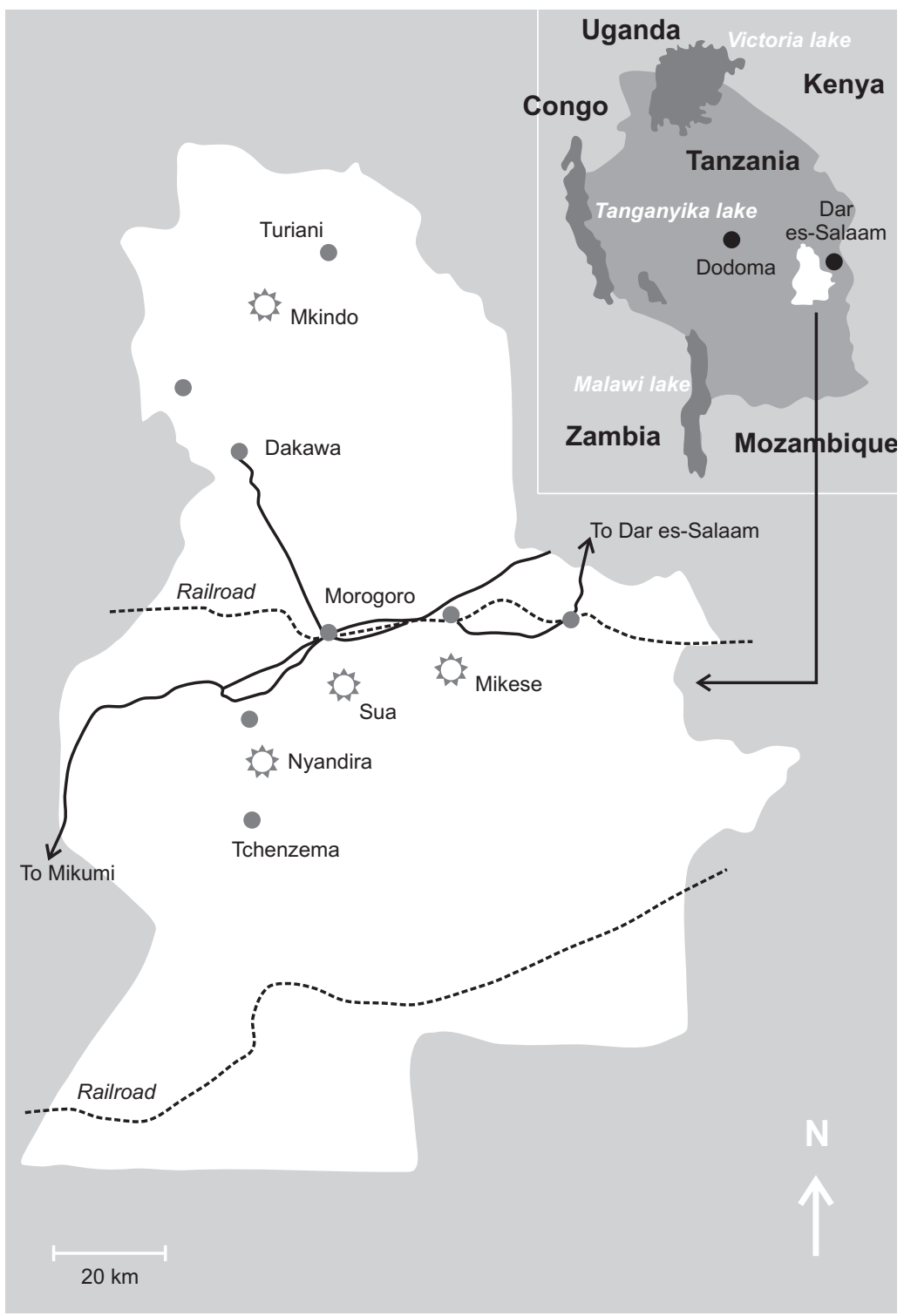


Table I.

Characteristics of the sites in Morogoro Region (Tanzania), studied to identify the biodiversity of fruit flies in orchards.

\begin{tabular}{|c|c|c|}
\hline Location & Description of the area & $\begin{array}{c}\text { Fruits cultivated } \\
\text { (common name and scientific name) }\end{array}$ \\
\hline 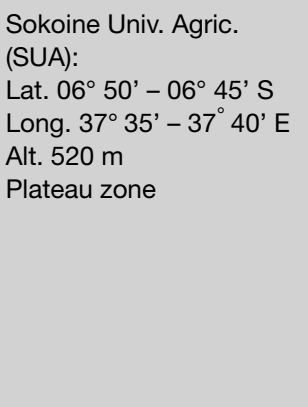 & $\begin{array}{l}15 \text { ha } \\
\text { A research, } \\
\text { demonstration and } \\
\text { semi-commercial } \\
\text { horticulture unit }\end{array}$ & $\begin{array}{l}\text { - Mango, Mangifera indica L.; tangerine, Citrus reticulata Blanco; lemon, Citrus limon (L.) } \\
\text { Burman f.; sweet orange, Citrus sinensis (L.) Osbeck. } \\
\text { - Also breadfruit, Artocarpus altilis (Parkins.) Fosb.; avocado, Persea americana Miller.; } \\
\text { governors' plum, Flacourtia indica (Burman f.) Merr.; guava, Psidium guajava L.; } \\
\text { grapefruit, Citrus paradisi Macfad.; soursop, Annona muricata L.; cherimoya, Annona } \\
\text { cherimola Miller; pomelo, Citrus grandis (Burman) Merr.; star fruit, Averrhoa carambola } \\
\text { L.; grapes, Vitis vinifera L.; passion fruit, Passiflora edulis f.s. flavicarpa; loquat, } \\
\text { Eriobotrya japonica (Thunb.) Lindley; kumquat, Fortunella margarita (Thunb.) Swingle; } \\
\text { jackfruit, Artocarpus heterophyllus Lam.; pawpaw, Carica papaya L.; and jew plum, } \\
\text { Spondias cytherea Sonn occur. } \\
\text { - In addition, different vegetable crops are grown, including cucurbits such as cucumber, } \\
\text { Cucumis sativus L. (table II lists all varieties grown here). }\end{array}$ \\
\hline $\begin{array}{l}\text { Mikese: } \\
\text { Lat. } 06^{\circ} 46^{\prime}-06^{\circ} 46^{\prime} \mathrm{S} \\
\text { Long. } 37^{\circ} 55^{\prime}-37^{\circ} 55^{\prime} \mathrm{E} \\
\text { Alt. } 390 \mathrm{~m} \\
\text { Plateau zone }\end{array}$ & $\begin{array}{l}8.6 \text { ha } \\
\text { A small commercial } \\
\text { orchard }\end{array}$ & $\begin{array}{l}\text { - Mango (varieties Maya, Red India, Kent, Tommy atkins), sweet orange, pawpaw and } \\
\text { avocado. } \\
\text { - Watermelon, Citrullus lanatus (L.) (grown in neighboring farms). }\end{array}$ \\
\hline $\begin{array}{l}\text { Mkindo: } \\
\text { Lat. } 06^{\circ} 14^{\prime}-06^{\circ} 14^{\prime} \mathrm{S} \\
\text { Long. } 37^{\circ} 33^{\prime}-37^{\circ} 33^{\prime} \mathrm{E} \\
\text { Alt. } 380 \mathrm{~m} \\
\text { River valleys and basin } \\
\text { zone }\end{array}$ & $\begin{array}{l}1.3 \text { ha } \\
\text { A smallholder orchard }\end{array}$ & - Sweet orange, lemon, mango, guava and coconut, Cocos nucifera L. \\
\hline $\begin{array}{l}\text { Nyandira: } \\
\text { Lat. } 7^{\circ} 05^{\prime}-7^{\circ} 00^{\prime} \mathrm{S} \\
\text { Long. } 37^{\circ} 30^{\prime}-37^{\circ} 35^{\prime} \mathrm{E} \\
\text { Alt. } 1650 \mathrm{~m} \\
\text { Mountainous area }\end{array}$ & $\begin{array}{l}2 \text { ha } \\
\text { A demonstration } \\
\text { orchard }\end{array}$ & $\begin{array}{l}\text { - Mainly temperate fruits are grown. } \\
\text { Fruits grown in the orchard include apple, Malus spp.; peach, Prunus persica (L.) } \\
\text { Batsch.; plum, Prunus salicina Lindley; strawberry, Fragaria spp.; coffee, Coffea } \\
\text { canephora Pierre ex A. Froehner; feijoa, Feijoa sellowiana (O. Berg) O. Berg.; guava, } \\
\text { Psidium spp.; nectarines, Prunus persica (L.) Batsch; loquat, cherimoya and avocado. }\end{array}$ \\
\hline
\end{tabular}

Table II.

Inventory of fruit varieties grown at Sokoine University of Agriculture (SUA) Horticulture Unit, Morogoro urban District, Tanzania.

\begin{tabular}{ll} 
Fruits & \multicolumn{1}{c}{ Varieties } \\
Citrus & - Orange: Valencia late, Early Valencia, Mediterranean sweet, Orlando, Sweet seedling, Hamlin, Pineapple, Casa grande \\
& oasis, Parson brown, Marsh early, Dan Joa, Matombo sweet, Binti Juma, Morogoro, Jaffa, Navelencia, Red Blush Ruby, \\
& Washington navel, Zanzibar. \\
& - Tangerines: Morogoro, Fairchild, Fortune, Dancy, Clementine, King, Kara, Murcott, Tangelo, Mandarin. \\
& - Grapefruit: Triumph, Dancan, Marsh seedless. \\
& - Lime: Tahiti. \\
& - Kumquat: Marumi. \\
Mango & Red Indian, Tommy Atkins, Kent, Keitt, Maya, Malgoba, Alphonso, Sandersha, Ngowe, Banda, Boribo Muyuni, Boribo Siagi, \\
& Boribo Nyekundu, Boribo Pemba, Dodo, Mwaka, Apple, Alizeti. \\
Guava & Pink, White.
\end{tabular}

\subsection{Identification}

Different types of keys were used: recent systematic revisions for Ceratitis and Trirhi- thrum [6-9] that were also incorporated in an unpublished digital multi-entry key [10]. For the dacines and other fruit flies, several other keys were used [11-13]. For Dacus 
Table III.

Numbers of insects (both sexes combined) of the different fruit fly species collected at four different study sites in Morogoro Region (Tanzania) (SUA: Sokoine University of Agriculture).

\begin{tabular}{|c|c|c|c|c|c|c|c|}
\hline Genus & Species & SUA & Mikese & Mkindo & Nyandira & Total & Percentage \\
\hline \multirow[t]{3}{*}{ Bactrocera } & amplexa & 1 & - & - & - & 1 & 0.0005 \\
\hline & cucurbitae & 1024 & 468 & 7 & - & 1499 & 0.7841 \\
\hline & invadens & 143384 & 23065 & 19138 & 27 & 185614 & 97.0866 \\
\hline \multirow[t]{9}{*}{ Dacus } & bivittatus & 98 & 50 & 16 & 7 & 171 & 0.0894 \\
\hline & chiwira & 5 & 13 & 1 & - & 19 & 0.0099 \\
\hline & ciliatus & 5 & 8 & & - & 13 & 0.0068 \\
\hline & durbanensis & 5 & & 1 & - & 6 & 0.0031 \\
\hline & humeralis & 137 & 71 & 15 & - & 223 & 0.1166 \\
\hline & hyalobasis & - & - & - & 15 & 15 & 0.0078 \\
\hline & katonae & - & 1 & - & - & 1 & 0.0005 \\
\hline & punctatifrons & 194 & 98 & 11 & 4 & 307 & 0.1606 \\
\hline & vertebratus & 5 & 8 & - & - & 13 & 0.0068 \\
\hline \multirow[t]{8}{*}{ Ceratitis } & aliena & - & - & - & 25 & 25 & 0.0131 \\
\hline & capitata & 62 & 33 & - & - & 95 & 0.0497 \\
\hline & cosyra & 96 & 63 & 2 & - & 161 & 0.0842 \\
\hline & dumeti & 1 & - & - & - & 1 & 0.0005 \\
\hline & fasciventris & 10 & - & - & 1 & 11 & 0.0058 \\
\hline & flexuosa & - & 1 & - & - & 1 & 0.0005 \\
\hline & rosa & 2204 & 53 & 3 & 701 & 2961 & 1.5488 \\
\hline & rubivora & - & - & - & 41 & 41 & 0.0214 \\
\hline Carpophthoromyia & dimidiata & - & 1 & - & - & 1 & 0.0005 \\
\hline Perilampis & cf. curta & - & 1 & - & - & 1 & 0.0005 \\
\hline Trirhithrum & coffeae & - & - & - & 4 & 4 & 0.0021 \\
\hline Total & & 147231 & 23934 & 19194 & 825 & 191184 & \\
\hline Total of species & & 15 & 15 & 9 & 9 & 23 & \\
\hline
\end{tabular}

taxa, when in doubt, confirmation of the identification was sought from Dr I. White (Natural History Museum, London, UK). Voucher specimens are kept in collections at the Sokoine University of Agriculture, Tanzania and the Royal Museum for Central Africa, Belgium.

\section{Results}

\subsection{Alpha diversity}

In total, over the full year's cycle, 191184 specimens were collected (table III). Of these, $97.087 \%$ belonged to Bactrocera invadens, while the second and third most common species (Ceratitis rosa and Bactrocera cucurbitae) represented 1.5488\% and $0.7841 \%$, respectively. The total number of all remaining fruit flies constituted less than $0.70 \%$ of the total catch. The SUA Horticultural Unit and Mikese sites showed the highest diversity, with 15 species found at each site. The Mkindo and Nyandira sites had a much lower diversity, with nine species found at each site. Four species were found in all four sites: Bactrocera invadens, Ceratitis rosa, Dacus bivittatus and D. punctatifrons, while Bactrocera cucurbitae, Ceratitis cosyra, Dacus chiwira and D. bumeralis were found at three out of the four sites. All species were previously reported in Tanzania. 
Table IV.

Number of insect catches per different type of trap at four different study sites in Morogoro Region (Tanzania).

\begin{tabular}{|c|c|c|c|c|c|c|}
\hline Genus & Species & Methyl eugenol & Cue lure & Trimed lure & Protein bait & Three-component lure \\
\hline \multicolumn{7}{|l|}{ Dacina } \\
\hline \multirow[t]{3}{*}{ Bactrocera } & amplexa & - & - & - & 1 & - \\
\hline & cucurbitae & - & 1170 & 4 & 319 & 6 \\
\hline & invadens & 180269 & 15 & 62 & 4944 & 324 \\
\hline \multirow[t]{9}{*}{ Dacus } & bivittatus & - & 150 & 1 & 20 & - \\
\hline & chiwira & - & 19 & - & - & - \\
\hline & ciliatus & - & 1 & - & 9 & 3 \\
\hline & durbanensis & - & 6 & - & - & - \\
\hline & humeralis & - & 219 & - & 4 & - \\
\hline & hyalobasis & - & 1 & - & 14 & - \\
\hline & katonae & - & - & - & 1 & - \\
\hline & punctatifrons & 1 & 285 & - & 21 & - \\
\hline & vertebratus & - & 4 & - & 9 & - \\
\hline \multicolumn{7}{|l|}{ Ceratitidina } \\
\hline \multirow[t]{8}{*}{ Ceratitis } & aliena & - & 1 & 2 & 21 & 1 \\
\hline & capitata & - & - & 77 & 10 & 8 \\
\hline & cosyra & - & - & 10 & 127 & 24 \\
\hline & dumeti & - & - & - & 1 & - \\
\hline & fasciventris & - & - & 10 & 1 & - \\
\hline & flexuosa & - & - & - & 1 & - \\
\hline & rosa & 12 & 10 & 1304 & 1005 & 630 \\
\hline & rubivora & - & - & 9 & 26 & 6 \\
\hline Carpophthoromyia & dimidiata & - & - & - & 1 & - \\
\hline Perilampis & cf. curta & - & - & - & 1 & - \\
\hline Trirhithrum & coffeae & - & - & - & 4 & - \\
\hline Total & & 180282 & 1881 & 1479 & 6540 & 1002 \\
\hline Total of species & & 3 & 12 & 9 & 21 & 8 \\
\hline
\end{tabular}

\subsubsection{Major pest species}

\subsubsection{Bactrocera cucurbitae (Coquillett)}

The melon fruit fly is a widespread pest species of Asian origin. The first African records date back to 1930 [14] and are from Kenya. Recently, it has also been found in western Africa [11]. Most East African records are from cultivated cucurbits such as cucumber (Cucumis sativus L.). Among the Dacus species attracted to cue lure, B. cucurbitae was the most abundant species (table IV).

\subsubsection{Bactrocera invadens Drew, Tsuruta \& White}

This species has been recorded very recently in Tanzania [3] and Benin [15]. It is an invasive species (probably of Asian ori- gin) that was introduced into Africa and it is spreading very fast throughout the continent [16]. Similar material, collected in Sri Lanka, was considered conspecific and the species was first described in 2005 [16]. Bactrocera invadens belongs to the B. dorsalis species complex, which harbors a number of important pest species such as B. carambolae, B. papayae and B. kandiensis [17]. In Africa, it seems to show a great dispersal power, attacking a wide variety of commercial fruit species.

\subsubsection{Ceratitis rosa Karsch / C. fasciventris (Bezzi)}

Ceratitis rosa or the Natal fruit fly is a major economic pest in southern and eastern Africa. It has been reported in several countries from South Africa northwards to Kenya 
[18]. It was also accidentally introduced into the island of Réunion where it largely replaced the equally introduced $C$. capitata [19]. It is a polyphagous species attacking a wide variety of unrelated fruits. So far, it has been reared from close to 100 hosts, belonging to 30 plant families [20]. Ceratitis fasciventris was considered a mere variety of C. rosa, but was recently ranked as a separate species, based on morphological and genetic studies [21-23]. Ceratitis fasciventris and C. rosa have a largely allopatric distribution, with $C$. fasciventris in western and Central Africa and occurring sympatrically only at certain sites in Kenya. A limited number of C. fasciventris specimens was found at two sites in Morogoro region (Nyandira and SUA), indicating CO-existence in these sites.

\subsubsection{Dacus bivittatus (Bigot)}

Dacus bivittatus, or the pumpkin fly, is one of the most common and widespread species of the genus Dacus. It has been reported in 28 African countries [11] distributed over the whole of the continent. It mainly attacks Cucurbitaceae such as cucumber and melon (Cucumis melo L.), but it is also reported from non-cucurbit hosts such as tomato (Lycopersicon esculentum Miller, Solanaceae).

\subsubsection{Dacus humeralis (Bezzi) / D. chiwira Hancock}

Dacus humeralis is found mainly in western and Central Africa, but it has also been recorded in Kenya, Tanzania and Uganda. Unlike most other Dacus species found in Morogoro region, for which we have confirmed host associations, D. humeralis is not reported from Cucurbitaceae but reared from Adenia gummifera (Passifloraceae). It is a variable species that closely resembles D. chiwira. Both species were found in the same sites. As indicated by White [11], the species status of both taxa needs to be studied further since the only consistent differentiating character (presence or absence of anterior supra-alar setae) is known to vary in other Dacus.

\subsubsection{Dacus punctatifrons Karsch}

Dacus punctatifrons is widespread and has been recorded in several African countries, with a (possible) adventive population in Yemen [24]. It attacks a wide range of Cucurbitaceae [11] but has also been reared from tomato and wild watermelon (Passiflora foetida, Passifloraceae).

\subsubsection{Minor pests}

\subsubsection{Ceratitis capitata (Wiedemann)}

Although the Mediterranean fruit fly is often considered the most harmful fruit fly, with an African origin [25] but spread over five continents and close to 400 host plants [20, 26], its presence in the Morogoro region seems to be limited, based on the trapping results. It was only found at two sites (Mikese and SUA) but never abundantly (table III). Whether this is due to environmental factors unfavorable to the establishment of this species (probably the case in Nyandira because of the colder climate at this high altitude) or a recent phenomenon due to displacement by other polyphagous species such as Bactrocera invadens needs to be assessed.

\subsubsection{Ceratitis cosyra (Walker)}

The mango fruit fly or marula fruit fly (C. cosyra) is a widespread species found throughout the African continent. It is a polyphagous pest, attacking close to 30 different fruit species [20]. It is considered the main fruit fly found in mangoes (Mangifera indica, Anacardiaceae), accounting for the major losses in mango production. However, in predominantly mango orchards such as Mikese and the traps in the mango part of SUA, its occurrence was relatively low (table III).

\subsubsection{Ceratitis rubivora Coquillett}

The blackberry fruit fly is found throughout southern and eastern Africa. As the common name already indicates, it is a stenophagous species attacking solely representatives of the genus Rubus [20].

\subsubsection{Dacus ciliatus Loew}

The lesser pumpkin fly (also known as Ethiopian fruit fly or cucurbit fly [24]) is a widespread species found throughout the African continent as well as the Indian Ocean 
Table V.

Diversity indices of the fruit fly populations at the different sites studied in Morogoro Region (Tanzania) (SUA: Sokoine University of Agriculture).

\begin{tabular}{lccc} 
Jaccard index & & & \\
Study site & Mkindo & SUA & Nyandira \\
\hline Mikese & 0.500 & 0.579 & 0.200 \\
Mkindo & - & 0.600 & 0.286 \\
SUA & - & - & 0.263 \\
\hline & & & \\
Sorensen index & & & \\
Study site & Mkindo & SUA & Nyandira \\
Mikese & 0.667 & 0.733 & 0.333 \\
Mkindo & - & 0.750 & 0.444 \\
SUA & - & - & 0.417
\end{tabular}

islands, Middle East and Oriental Asia [24]. It attacks a wide variety of cucurbit fruits such as several Cucumis species, pumpkin (Cucurbita maxima Duchesne) and Momordica spp. There are also some records from non-cucurbit hosts such as tomato or beans that need confirmation [11]. Morphologically it is a very variable species. The species was present in low numbers in the traps used in this study, and only in the food attraction types.

\subsubsection{Dacus vertebratus Bezzi}

The melon fly is also a known pest of cucurbit crops, especially watermelon (Citrullus lanatus) and several Cucumis spp. [11]. It is found throughout the African continent and the Middle East. According to White [11], this species differs from D. ciliatus in usually having the laterotergal xanthine across the anatergite as well as katatergite, which is the case in our specimens. However, some of the specimens were collected in a cue lure trap, which was not expected for the species.

\subsubsection{Trirhithrum coffeae Bezzi}

The coffee fruit fly attacks the berries of Coffea species (such as Coffea canephora Pierre ex Froehner, but also C. arabica L. in small numbers) although the infestation does not seem to have a detrimental effect on coffee production [9]. Its taxonomic position and confusion with other Trirhithrum species such as T. nigerrimum Bezzi and T. inscriptum (Graham) have only recently been clarified [9].

\subsubsection{Other fruit flies}

Nine other species of fruit flies were collected at the different sites. In most cases, these were single specimens of species of no economic importance, including $\mathrm{Bac}$ trocera amplexa (Munro), Dacus katonae Bezzi, Carpophthoromyia dimidiata Bezzi, Ceratitis dumeti Munro, C. flexuosa (Walker), and Perilampsis sp. probably curta Munro. Dacus durbanensis Munro, D. byalobasis Bezzi and Ceratitis aliena (Bezzi) were occasionally found in relatively low numbers at one or two sites.

\subsection{Beta diversity}

Beta diversity measures how different or similar habitats or samples are in terms of the variety of species found in them [5]. In this case, the species composition of the different study sites was compared. The results of the different traps are pooled. Only the presence and absence data are used, since the differences in attractiveness of the different lures used do not allow use of quantitative data. The Jaccard and qualitative Sorensen indices were calculated according to the formulae provided by Magurran [5]. These indices are equal to 1 when there is complete similarity and to 0 if the sites have no species in common. In our studies, the highest similarity was observed between SUA, Mkindo and Mikese (table V). All these are low-altitude areas $(380-520 \mathrm{~m})$. The Nyandira site at high altitude $(1650 \mathrm{~m})$ had the lowest indices with respect to all the other sites, indicating that it had quite different species composition.

\subsection{Lure response}

Parapheromone baits such as methyl eugenol are very specific and only collected a limited number of flies, while protein bait and synthetic food attractant (three-component lure) attracted a much wider spectrum of flies (table $I V)$. 


\section{Discussion}

\subsection{Pest species composition}

Among the dominant species found at all sites studied in the Morogoro region (Tanzania), several species of the genera Ceratitis and Dacus were represented. Members of the genus Ceratitis, such as C. rosa C. capitata and C. cosyra, are known economic pests attacking a wide variety of fleshy fruits. In addition, the invasive Bactrocera invadens was prevalent in three of the four sites. Hosts for afrotropical Dacus species appear to belong to three plant families, namely Cucurbitaceae, Passifloraceae and Asclepiadaceae (the latter included nowadays under Apocynaceae) [11]. The phylogenetic relationship between species groups or subgenera recognized within the genus Dacus and host utilization was recently studied [11]. The homoplastic nature of the observed host range is, however, not fully clarified. The dominant representatives of the genus Dacus that were collected at the study sites are all cucurbit feeders. In general, it can be stated that the major fruit fly pests that occur in Tanzania, as listed by Mwatawala et al. [3], were recorded from the study sites in the Morogoro region.

The other species found were usually present in low numbers, often represented by a single specimen (as is the case for $\mathrm{Bac}$ trocera amplexa, Carpophthoromyia dimidiata, Ceratitis dumeti, C. flexuosa, Perilampsis cf. curta and Dacus katonae). These species are of no economic importance, and often with stenophagous or monophagous host range among indigenous fruits. Ceratitis flexuosa is sometimes associated with mangoes in western Africa but always in low numbers [20, 27]. Whether it routinely attacks mangoes has still to be confirmed.

SUA is the most diverse site with regard to available hosts with fleshy fruits. Mikese is much less diverse in potential hosts but shows an equally diverse fruit fly fauna. However, a large proportion of the observed Mikese fruit fly fauna was represented by single specimens of species with little or no economic importance. This is therefore more a reflection of the total host availability in the surroundings, including indigenous wild hosts, rather than the fruit fly pest fauna.

\subsection{Beta diversity}

A large similarity was observed between the three sites at low and medium altitude. Only Nyandira, at high altitude, shows a remarkable dissimilar fauna compared with the other three sites. This is most likely caused by the different range of fruits available at the Nyandira site. These are mainly temperate fruits and crops that need colder conditions, including apple, peach, plum and coffee. Also, a Rubus sp. and Solanum sp. were observed here during site visits (hosts for, respectively, Ceratitis rubivora and C. aliena); they were not observed at the other sites. On the other hand, cucurbit infesters such as Bactrocera cucurbitae, Dacus punctatifrons or D. bivittatus were absent, or present only in comparatively very low numbers. The invasive Bactrocera invadens, present in high numbers at the other sites, was found at this site also in relatively very low numbers and only part of the year. Apparently, the climatic conditions present in Nyandira seem to cause a barrier for the establishment of this species at this altitude. This should be tested, however, in experimental settings to test the survival and development of different life stages against a gradient of different temperatures. Similar studies for $C$. capitata and $C$. rosa have shown a higher tolerance of $C$. rosa to low temperatures by lower temperature thresholds in the laboratory [28]. Bactrocera invadens may possibly outcompete native polyphagous species such as Ceratitis capitata or C. rosa in certain regions, depending on environmental conditions.

\subsection{Lure response}

Lure response is specific, with each parapheromone attracting a subset of species of different genera. In general, the lure response corresponds to published records for the different species. Methyl eugenol (ME) is known to attract Bactrocera invadens but none of the other dacines in Africa. In addition, it attracts Ceratitis spp. belonging to the subgenus Pardalaspis, but apparently none of these were present at the study sites. Cue lure (CL) is known to attract a number of Dacus species, especially in those groups that are associated with Cucurbitaceae or 
Passifloraceae. Trimedlure (TM) attracts representatives of the subgenera Ceratitis s.s. and C. Pterandrus. The efficiency of each parapheromone is different. For example, $\mathrm{ME}$ is known to be very potent and this might be the reason for high numbers of Bactrocera invadens. However, field observations and the catches in protein-bait traps do show B. invadens as the dominant species in three of the four sites. Only in Nyandira was Ceratitis rosa the dominant species found. Protein bait (PB) and threecomponent (3C) lure are actually attractants that do not operate as (para)pheromones but as food substances required for proper development of eggs. Therefore, they are more general than the specific parapheromone lures, and their captures might reflect more the proportional presence of the different fruit flies in the particular environments. On the other hand, the radius over which they attract flies is much smaller than that of parapheromones and therefore presents better the fruit fly fauna immediately surrounding the site where a trap is placed, rather than a larger area. PB trap results were the second highest in total number of specimens caught and the highest in number of taxa. All taxa found in the different study sites, except for two (D. chiwira and D. durbanensis), were captured with $\mathrm{PB}$ traps. Compared with the PB trap results, the efficiency of the $3 \mathrm{C}$ bait was much lower. This could, however, be due to the fact that the development of the synthetic lure attractant is still at an experimental stage and that the different components are not yet fully optimized (Holler, pers. comm.).

Occasionally aberrant records of specimens were found in lures from which they are usually not recorded. For example, several specimens of Bactrocera invadens were found in TM and CL traps (table IV). There was also the occasional C. rosa in ME or CL traps, and Dacus bivittatus in TM traps. However, this seems to be the result of accidental introductions into these particular traps and most likely does not reflect a true parapheromone response. In general, all known lures for different species are confirmed in this study. Species such as C. byalobasis and D. ciliatus, which are known not to be attracted to the paraphe- romones used, were either absent or present in very low numbers, in which case they are attributed to accidental entries. Ceratitis rubivora is reported to be attracted to TM [29]. This was also observed in our study, albeit in much lower numbers than, for example, in the protein-bait trap. It could be that TM is only weakly attractive to C. rubivora. A few specimens of D. vertebratus were collected in CL traps. D. vertebratus is usually attracted to vert lure (methyl-4-hydroxybenzoate), while the closely related $D$. frontalis is attracted to CL [11]. Vert lure was not used in our survey and the specimens key out to C. vertebratus with regard to diagnostic characters of femur coloration and apical wing spot. There is, therefore, no full correspondence in this study with earlier reports and the matter needs further investigation.

\subsection{Impact of Bactrocera invadens on indigenous fruit fly diversity}

Several of the fruit fly species found in this area belong to the traditional major fruit pests recognized for the region, such as C. capitata, C. cosyra and C. rosa. The relative abundance of these flies, however, seems to be affected by the recently introduced alien Bactrocera invadens. It appears that this alien is outcompeting and replacing the indigenous pests, a phenomenon that has been observed repeatedly in fruit fly invasions [19]. Abiotic environmental aspects may have an effect on the occurrence and dominance of the alien species though, as has been observed by the relatively low numbers of $C$. capitata at low altitudes but the dominance of the indigenous $C$. rosa at higher and colder altitudes, where B. invadens appears not to be established. Agro-systems at different altitudes have a different species composition and the impact of the alien species differs accordingly. The data so far seem to indicate that $B$. invadens should be considered as a serious pest threatening the horticultural industry in the whole Sub-Saharan region and that it may have a considerable impact on the local fruit fly fauna. A detailed study of its ecology and population dynamics and development of adequate control mechanisms should, therefore, be considered a high priority. 


\section{Acknowledgements}

Many thanks to F.J. Senkondo, Lilian Shechambo, Resta Maganga and Y. Mgoba (Sokoine Univ. Agric., Tanzania) for their assistance in the field, to I.M. White (Natural History Museum, London, UK) for confirmation of Dacus identifications and making available his forthcoming revision on dacines of the Afrotropical region, and to N. Van Noppen for adjustment of the map. This study was financially supported by the Belgian Development Cooperation through the Framework program with the Royal Museum for Central Africa (Project F13). Two anonymous referees provided constructive comments that improved an earlier draft of this article.

\section{References}

[1] Lux S.A., African fruit fly initiative: Pan-African initiative to promote productivity and trade of fruits and vegetables through management of African fruit flies, ICIPE, Nairobi, 1999, 28 p.

[2] Mwatawala M.W., Senkondo F.J., Maerere A.P., De Meyer M., Current status and future needs for fruit flies research in Tanzania, Int. Pest Control 47 (2005) 184-187.

[3] Mwatawala M.W., White I.M., Maerere A.P., Senkondo F.J., De Meyer M., A new invasive Bactrocera species (Diptera: Tephritidae) in Tanzania, Afr. Entomol. 12 (2004) 154-158.

[4] Banwo O.O., Adamu R.S., Insect pest management in African agriculture: challenges in the current millennium, Arch. Phytopathol. Plant Prot. 36 (2003) 59-68.

[5] Magurran A.E., Ecological diversity and its measurement, Croom Helm, London, UK, 1988, $179 \mathrm{p}$.

[6] De Meyer M., Revision of the subgenus Ceratitis (Ceratalaspis) Hancock (Diptera: Tephritidae), Bull. Entomol. Res. 88 (1988) 257-290.

[7] De Meyer M., Systematic revision of the subgenus Ceratitis MacLeay s. s. (Diptera: Tephritidae), Zool. J. Linn. Soc. 128 (2000) 439-467.

[8] De Meyer M., Freidberg A., Revision of the subgenus Ceratitis (Pterandrus) Bezzi (Diptera: Tephritidae), Proc. 1st Tephridologists Meet., Israel (in press).
[9] White I.M., Copeland R.S., Hancock D.L., Revision of the afrotropical genus Trirhithrum Bezzi (Diptera: Tephritidae), Cimbebasia 18 (2003) 71-137.

[10] White I.M., De Meyer M., Cabi key for the genus Ceratitis MacLeay. Natural History Museum, London and Africamuseum, Tervuren, UK, 2000, CD-rom (beta version).

[11] White I.M., Taxonomy of the Dacina (Diptera: Tephritidae) of Africa and the Middle East, Afr. Entomol. Mem. 2 (2006) 7-156.

[12] De Meyer M., Systematic revision of the fruit fly genus Carpophthoromyia Austen (Diptera, Tephritidae), Zootaxa 1235 (2006 1-48.

[13] Hancock D.L., Keys to African species of Ceratitidini, unpubl. Manuscr., Cairns, Australia, $20 \mathrm{p}$.

[14] Munro H.K., A taxonomic treatise of the Dacidae (Tephritoidea, Diptera) of Africa, Dep. Agric. WaterSupply, Entomol. Mem., 61, S. Afr., 1984, 313 p.

[15] Vayssières J.F., Georgen G., Lokossou O., Dossa P., Akponon C., A new Bactrocera species in Benin among mango fruit fly (Diptera: Tephritidae) species, Fruits 60 (2005) 371-377.

[16] Drew R.A.I., Tsuruta K., White I.M., A new species of pest fruit fly (Diptera: Tephritidae: Dacinae) from Sri Lanka and Africa, Afr. Entomol. 13 (2005) 149-154.

[17] Drew R.A.I., Hancock D.L., The Bactrocera dorsalis complex of fruit flies (Diptera: Tephritidae: Daciniae) in Asia, Bull. Entomol. Res. Suppl. 2 (1994) 1-68.

[18] De Meyer M., Distribution patterns and hostplant relationships within the genus Ceratitis MacLeay (Diptera: Tephritidae) in Africa, Cimbebasia 17 (2001) 219-228.

[19] Duyck P.-F., David P., Quilici S., A review of relationships between interspecific competition and invasions in fruit flies (Diptera: Tephritidae), Ecol. Entomol. 29 (2004) 511520.

[20] De Meyer M., Copeland R.S., Lux S.A., Mansell M., Quilici S., Wharton R., White I.M., Zenz N.J., Annotated check list of host plants for afrotropical fruit flies (Diptera: Tephritidae) of the genus Ceratitis, Mus. R. Afr. Cent., Doc. Zool., vol. 27, Tervuren, Belgium, 2002, $91 \mathrm{p}$.

[21] De Meyer M., On the identity of the Natal fruit fly Ceratitis rosa Karsch (Diptera, Tephritidae), Bull. Inst. Rech. Sci. Natl. Belg., Entomol. 71 (2001) 55-62. 
[22] Baliraine F.N., Bonizzoni M., Osir E.O., Lux S.A., Mulaa F.J., Zheng L., Gomulski L.M., Gasperi G., Malacrida A.R., Comparative analysis of microsatellite loci in four fruit fly species of the genus Ceratitis (Diptera: Tephritidae), Bull. Entomol. Res. 93 (2003) 1-10.

[23] Baliraine F.N., Bonizzoni M., Guglielmino C.R., Osir E.O., Lux S.A., Mulaa F.J., Gomulski L.M., Zheng L., Quilici S., Gasperi G., Malacrida A.R., Population genetics of the potentially invasive African fruit fly species, Ceratitis rosa and Ceratitis fasciventris (Diptera: Tephritidae), Mol. Ecol. 13 (2004) 683-695.

[24] White I. M., Elson-Harris M.M., Fruit flies of economic significance: their identification and bionomics, $\mathrm{CAB}$ International, Wallington, Oxon, UK, 1992, $601 \mathrm{p}$.

[25] De Meyer M., Copeland R.S., Wharton R.A., McPheron B.A., On the geographical origin of the medfly, Ceratitis capitata (Wiedemann) (Diptera: Tephritidae), in: Barnes B. (Ed.), Proc. 6th Int. Symp. Fruit Flies Econ. Impor- tance, Isteg Sci. Publ., Stellenbosch, S. Afr., 2002, 45-53.

[26] Liquido N.J., Barr P.G., Cunningham R.T., MEDHOST, an encyclopedic bibliography of the host plants of the Mediterranean fruit fly, Ceratitis capitata (Wiedemann), version 1, in: Thompson F.C. (Ed.), Fruit fly expert identification system and systematic information database, Diptera dissemination disk 1, Washington DC, USA, 1998.

[27] Vayssières J.-F., Kalabane S., Inventory and fluctuations of the catches of Diptera Tephritidae associated with mangoes in Coastal Guinea, Fruits 55 (2000) 259-270.

[28] Duyck P.F., Quilici S., Survival and development of different life stages of three Ceratitis spp. (Diptera : Tephritidae) reared at five constant temperatures, Bull. Entomol. Res. 92 (2002) 461-469.

[29] Hancock D.L., Notes on some African Ceratitinae (Diptera Tephritidae) with special reference to the Zimbabwean fauna, Trans. Zimb. Sci. Assoc. 63 (1987) 47-57.

\section{Biodiversidad de las moscas de la fruta (Diptera, Tephritidae) en vergeles, en diferentes zonas agro-ecológicas de la región de Morogoro, Tanzania.}

Resumen - Introducción. Las moscas de la fruta (Diptera, Tephritidae) se encuentran entre los máximos obstáculos de la horticultura comercial en numerosos países africanos en vía de desarrollo. El conocimiento del espectro de los tefritidos en un sector determinado es un prerrequisito para el desarrollo de un programa de IPM, que permita atenuar el problema parasitario. Estudiamos la diversidad de las moscas de la fruta en cuatro zonas principales agro-ecológicas, que son zonas de importante producción fructífera en la región de Morogoro, Tanzania. Material y métodos. Se estudió durante un año (desde octubre 2004 hasta octubre 2005) la diversidad de las moscas de la fruta. Con el fin de atrapar las moscas se utilizaron en diferentes lugares de la región de Morogoro unas trampas basadas en paraferomonas, atrayentes alimenticios sintéticos y cebos proteinados. Se eligió un vergel compuesto para cada uno de los cuatro lugares representativos de las diferentes zonas agro-ecológicas de la región. Resultados. Se encontraron en los cuatro emplazamientos prospectados la especie extranjera introducida recientemente Bactrocera invadens, así como otras tres especies dañinas autóctonas Ceratitis rosa, Dacus bivittatus y D. punctatifrons, mientras que Bactrocera cucurbitae, Ceratitis cosyra, Dacus chiwira y D. humeralis fueron encontrados en tres de los cuatro emplazamientos visitados. Los sitios de la universidad de horticultura y de agricultura de Sokoine (SUA) y de Mikese revelaron la diversidad de especies más elevada, mientras que las localidades de Mkindo y de Nyandira mostraron una diversidad más baja. La diversidad intra-habitats (diversidad-bêta) fue la misma para los sitios de SUA, Mkindo y Mikese. Únicamente la localidad de Nyandira reveló una disimilitud más importante que la de los otros tres emplazamientos. Discusión. La especie más abundante en altitudes baja y media fue Bactrocera invadens, mientras que, en elevada altitud, Ceratitis rosa fue la especie dominante. Las trampas con cebo proteinado atrajeron la diversidad de moscas de la fruta más marcada en relación con las paraferomonas más específicas. El atrayente alimenticio sintético (cebo de tres componentes) fue menos eficaz en comparación con el cebo proteinado. La gran disimilitud observada en Nyandira se debe probablemente a los diferentes tipos de frutos huéspedes encontrados y cultivados en este lugar de elevada altitud, principalmente frutos temperados. Especies de moscas de la fruta asociadas a estos tipos de frutos, por ejemplo, Ceratitis rubivora y Trirbithrum coffeae, se encontraron sólo en este emplazamiento.

Tanzanía / árboles frutales / Tephritidae / mosca de la fruta / biodiversidad / Ceratitis / Bactrocera / Dacus / encuestas / trampas / identificación 